\title{
The 21 May 2003 Zemmouri (Algeria) Earthquake: Damages and Disaster Responses
}

\author{
Hakim Bechtoula ${ }^{1}$ and Hassane Ousalem ${ }^{2}$
}

Received 11 June 2004, accepted 29 September 2004

\begin{abstract}
A large number of reinforced concrete buildings collapsed or were heavily damaged during the 6.8 magnitude Zemmouri earthquake that struck northern Algeria on 21 May 2003. A technical survey campaign was launched to assess damages and losses in the most affected areas in Algiers and Boumerdes prefectures. Reinforced concrete frame structures and apartment buildings were the most damaged categories. Buildings with shear walls or steel frames performed well. Analyses of collected data showed that damage was randomly distributed in different localities. Results and observations highlighted the following deficiencies: poor quality of materials, poor quality of construction, insufficient element sizes and dimensions, lack of good detailing and poor design. This paper also reviews the seismic hazard preparedness and disaster response, including emergency relief, administrative, technical and scientific issues, and social issues. Finally, lessons from the catastrophic event and future needs are summarized.
\end{abstract}

\section{Introduction}

On 21 May 2003, at 19:45 local time, a severe earthquake with a magnitude of $6.8\left(\mathrm{M}_{\mathrm{w}}\right)$ occurred in the northern-central part of Algeria, which lies near the borderline separating the African Plate from the Eurasian Plate. The epicenter was located in the Mediterranean Sea (CRAAG, 2003), seven kilometers north of Zemmouri city in Boumerdes Prefecture, and 60 kilometers east of Algiers, the capital (Fig. 1). The surface of the rupture was estimated at 15 to 20 kilometers extending into the sea, where the fault slipped approximately 1 meter. The earthquake's effect reached all the way the Balearic Islands, Spain, where a tsunami destroyed more than 100 yachts and fishing boats (EQnet, 2003; Azurséisme, 2003).

Analyses of recorded tremors showed that the period of strongest motion parts lasted approximately $10 \mathrm{sec}-$ onds (Fig. 2) and the frequencies were concentrated in the band of 4 to $10 \mathrm{~Hz}$. In some locations, acceleration of $0.4 \mathrm{~g}$ for the vertical component and $0.58 \mathrm{~g}$ for the horizontal component were recorded (Laouami et al., 2003). The main shock was followed by severe tremors with high magnitudes, inducing severe damages and disturbing and/or disrupting services, facilities and lifelines in the region (Bossu et al., 2003). The worst affected prefectures were Boumerdes and Algiers. Officially, 2,278 people died, 11,450 suffered injuries, and more than 180,000 were made homeless. Some 10,280 constructions collapsed, resulting in direct economic loss amounting to US\$5 billion at a first estimation

${ }^{1} \mathrm{Ph}$. D. Student, Department of Architecture and Architectural Systems, Kyoto University, Kyoto Japan. E-mail: rc.hakim@archi.kyoto-u.ac.jp

${ }^{2} \mathrm{Ph}$. D. Student, Department of Architecture, The University of Tokyo, Tokyo, Japan.
(CNGC, 2003).

\section{Surface breaks, landslides and liquefaction}

Based on the damages observed in the affected region, a few places showed geotechnical problems. Actually, the randomness of the damage observed in the various inspected locations, including slopes, soft soil areas and the seashore, suggest that damages resulted mainly from structural and quality deficiencies and were not due to topographic conditions and geotechnical factors such as tilting, subsidence, settlement and sliding. Unfortunately, soil data required to grasp, in depth, the causes of damages, were not available and could not be obtained at the time of investigation.

However, some observations have been made as to liquefaction, rock falling, landslides and topography deformation (Ousalem and Bechtoula, 2003).

\subsection{Coastal uplift}

Uplift of the seafloor along the coastline for almost 80 kilometers was observed. The cliff and flat coastal land south of the fault uplifted in some places more than 50 $\mathrm{cm}$. At Zemmouri and Dellys harbors, the difference in levels was approximately $60 \mathrm{~cm}$ (Fig. 3 and Fig. 4). Also, on the rocky seashore of Dellys, many rock blocks, which had always been covered by seawater, emerged after the main shock.

\subsection{Liquefaction, soil deformation and cracks}

Due to the liquefaction phenomena, a significant number of sand boils was observed nearby the Isser and Sebaou rivers between Boumerdes city and Zemmouri city (Fig. 5), and several cracks appeared in the free fields and nearby roads parallel to the river banks due to ground movements toward the rivers (Fig. 6). 


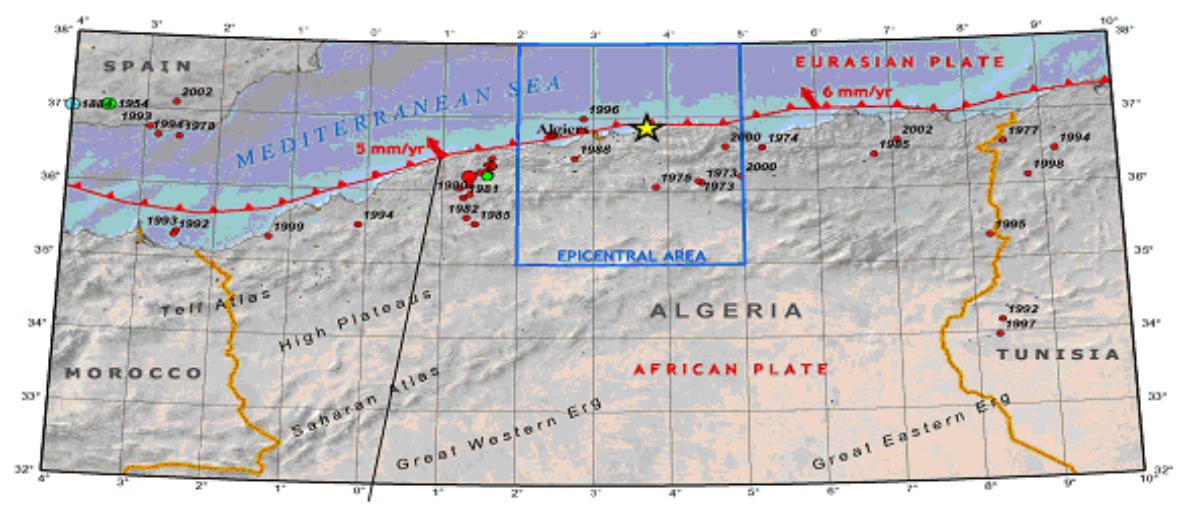

Fig. 1 Epicenter location and borderline between Eurasian and African plates (from EQnet).

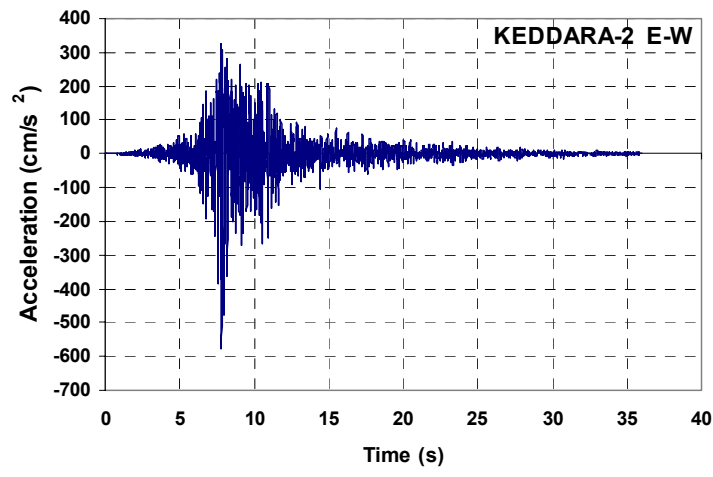

Fig. 2 Recorded horizontal acceleration at Kedara site.

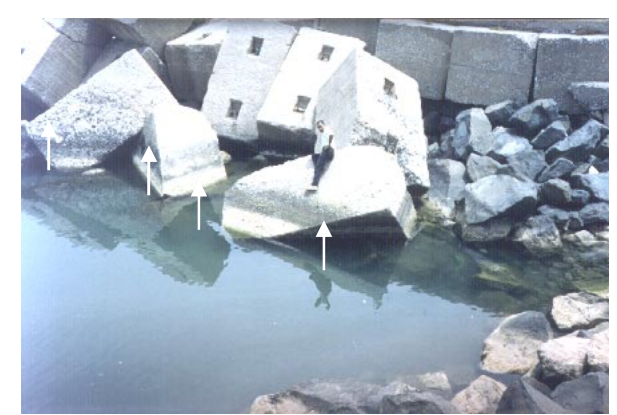

Fig. 3 Uplift of the seafloor at Dellys harbor.

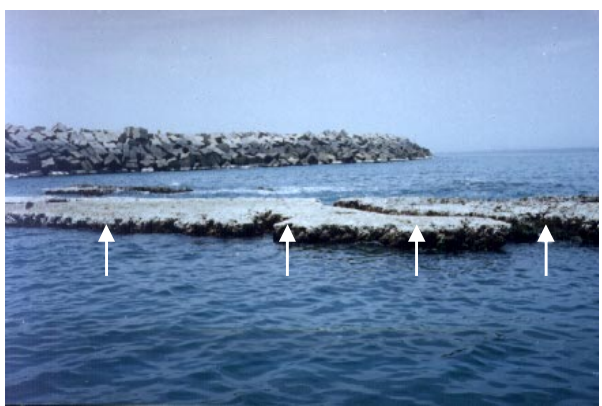

Fig. 4 Emerging flat rocks on the seashore.

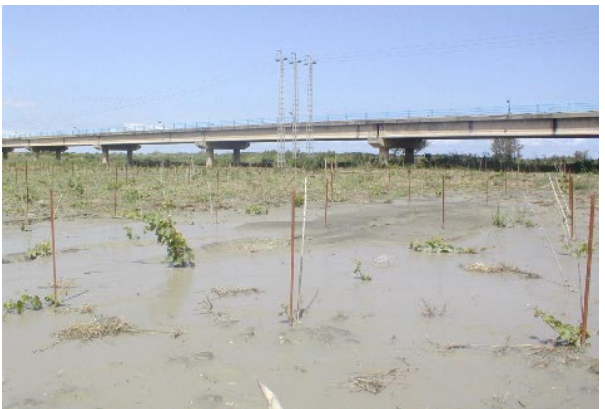

Fig. 5 Sand boils nearby riverside.

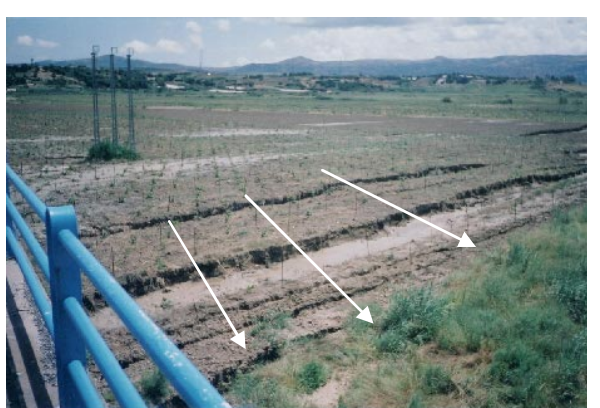

Fig. 6 Cracks and land spreading toward river.

\subsection{Land slides and rock falls}

In mountains areas, few slight landslides were observed near roads (Fig. 7) and some heavy rocks detached from hills (Fig. 8) and fell down near some villages while some other rocks remained in unstable positions, exposing some localities to permanent danger in case of future strong tremors.

\section{Building procedures and construction practice}

Although shear wall structures are common, reinforced concrete frame constructions are the most popular in Algeria, particularly for buildings of up to 10 stories. 
Hollow brick masonry infill walls are often used to separate interior building areas while exterior panels are also executed using hollow bricks but with two infill walls (Fig. 9 and Fig. 10).

For high-rise buildings of more than 15 stories, reinforced concrete shear wall structures are used. In some cases, mixed structures, frames and shear walls are used External panels are either executed with masonry infill walls or prefabricated reinforced concrete panels. Recently, glass panels are also being set as the façades for modern buildings.

Steel structures are also used for buildings but they account for a negligible number compared to reinforced concrete structures. Steel structures are more popular in the field of industry.

While the construction process of medium to highrise buildings is mechanized, with strict material control and the use of qualified labor, low-rise buildings are generally constructed by non-engineer contractors who still rely on manpower for preparing and casting concrete, resulting in buildings with low seismic performance.

\section{Algerian construction requirements}

Depending on the type of structures, at least two different regulations influence the design and construction of buildings in Algeria. While the seismic code "Règles parasismiques Algériennes - RPA 99” includes design, detailing and procedures for calculating structural dynamic characteristics and earthquake loads on buildings of any type, it stresses reinforced concrete structures with more details and directs designers and contractors toward other regulations when it comes to specific types, like steel or mixed structures (CGS, 1988 and 1999). The building code requirements for reinforced concrete, "Règles de conception et de calcul des structures en béton armé - CBA 93", the building code requirements for steel, "Règles de conception et de calcul des structures métalliques - CCM 97", and the building code requirements for mixed structures, "Règles de conception et de calcul des structures mixtes acier-béton" present requirements for the design and detailing of each type of corresponding material components with few details about seismic design. For instance, in the case of reinforced concrete, the code does not include sufficient ductile detailing for use in seismic zones (CGS, 1993). Such requirements, however, are found in seismic regulations.

As to soil requirements, there are no specific and detailed regulations for this purpose, although the state of the art of recent knowledge is applied for engineered constructions.

Also, while these regulations as well as insurance are mandatory for public facilities, the law did not impose such requirements on private owners prior to the Zemmouri earthquake.

\section{Algerian seismic regulations}

Algeria is a seismic country and as such familiar with earthquake, especially during the last 50 years. Although engineering ability in the construction field has

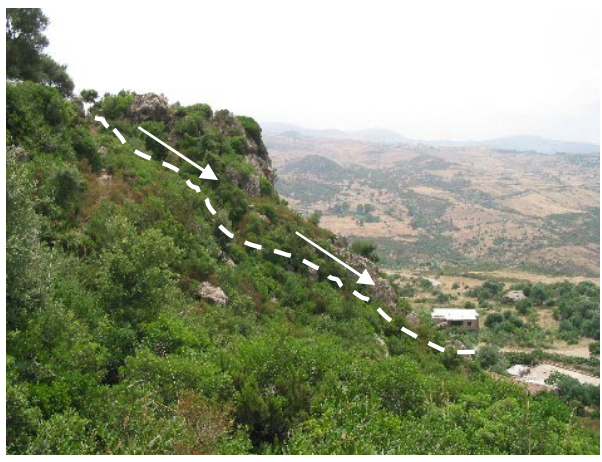

Fig. 7 View of a threatened slope.

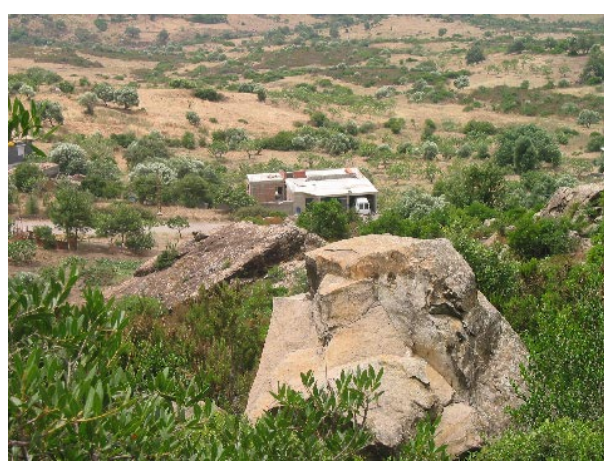

Fig. 8 Rocks that have fallen towards a village.

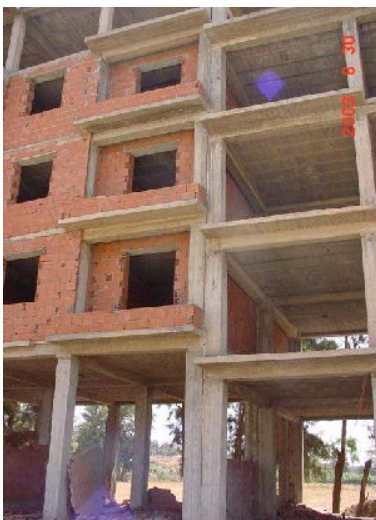

Fig. $9 \mathrm{RC}$ frames and settings of infill walls.

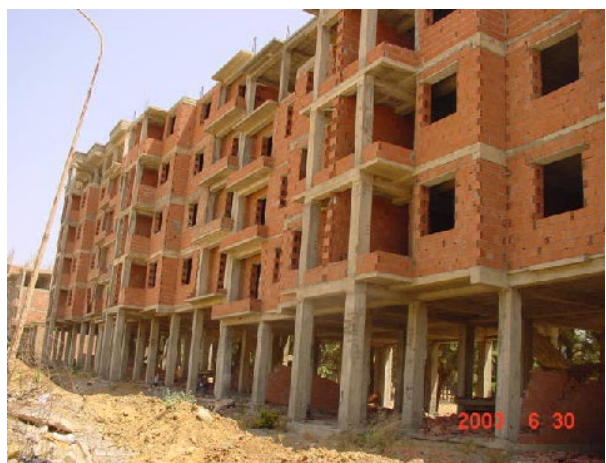

Fig. 10 Upper story infill walls. 
been increasing since the country's independence in 1962, earthquake engineering has a short history in Algeria that began after El-Asnam earthquake in 1980 and, unfortunately, has not progressed at the same pace as other sectors in order to satisfactorily meet the building challenges of the nation.

Academics and engineers have inherited and used French seismic recommendations AS-55, which were subsequently improved and renamed PS-69. In 1980, Algerian academics and engineers, with international help, particularly from Stanford University, published the first truly Algerian seismic regulations, named RPA81 (Règlement Parasismique Algérien 1981). These regulations cover four main aspects: definitions and technical rules, seismic zoning and soil categories, constructions grading and process, and finally computation methods and safety validations.

Since 1981, some part of the code have been revised based on lessons learned from earthquake events both in Algeria and abroad as well as on research advances, resulting in three versions that appeared successively in 1983, 1988 and 1999. The added or improved parts in the regulations focused on technical and economical aspects, with the most important dealing with geotechnical investigations (compulsory detailed seismic investigations for moderate to high-rise buildings, like liquefaction, sliding, etc...), seismic-zoning, sites classification and design response spectra (some districts or regions upgraded to higher seismic levels and new soil categories delimited with their corresponding design spectra), damage level control (facilities importance and grading improved by more detailed definitions and refined design factors), materials and construction processes (restrictions on some materials, assembling processes and applied techniques), computation methods and modeling (support of general methodologies and scientific formulations and advice on detailed analyses), quality control and design (reduction of some restrictions and penalty factors for material quality, design and field control), evaluation of induced seismic forces (improving building vibration period formulation, readjusting building global performance factors according to required responses, re-evaluating acceleration values according to new hazard events and recent studies).

The philosophy of these regulations is the same, where the formula for the design base shear force, $Q$, is given as

$$
\mathrm{Q}=\mathrm{CW}
$$

where $\mathrm{W}$ is the total structural weight including a part of live loads and $\mathrm{C}$ is the seismic coefficient, obtained from a successive multiplication of other factors like the acceleration zone coefficient, the spectral coefficient, the structural type coefficient and the construction importance factor. For the majority of building structures in the affected area, the design base shear, according to regulations before 1980 and after is, respectively, around $6 \%$ and $12 \%$ of the building weight. Earthquake records and recent seismic studies have proved that the actual base shear value of the evaluated buildings is higher than the previously assessed values, usually approximately $20 \%$ and as high as $30 \%$ in some cases.

\section{Performance of facilities during the Zemmouri earthquake}

During the event, the most affected areas were those near the epicenter. Also, constructions and facilities in the affected zones, mainly in Boumerdes and Algiers prefectures, responded differently to the tremors. Some of the facilities sustained all tremors, others sustained the main shock but fell down during the aftershocks, while others still collapsed from the first vibrations. Different kinds of collapses occurred, including pancake collapse, first floor collapse and medium floor collapse were observed everywhere in the affected zones.

Based on the investigation, serious building damages were mainly caused by the poor quality of building materials, insufficient element sections and lack of adequate structural design. Furthermore, damages were also caused by the severity and amplification of ground motions due to the probable existence of soft deposits near the ground surface, though no traces of liquefaction, subsidence of foundations, or inclination of buildings were noticed during the investigation of the region.

The distribution of damage on constructions was evaluated according to the general data obtained from the administration offices (DUC, 2003) of Algiers and Boumerdes prefectures, while the evaluation of damage was based on a technical form, similar to the European Macroseismic Scale (ESC, 1998), which was filled out by engineers in the field. The classification of damage resulted in five grades, ranging from negligible or slight damage (Grade- 1) to very heavy damage or collapse (Grade- 5), as summarized in Table1.

\subsection{Distribution of damage in the prefecture of Boumerdes}

The most affected areas in the prefecture of Boumerdes

Table 1 Classification of damage.

\begin{tabular}{|c|l|}
\hline Grade & \multicolumn{1}{|c|}{ Description } \\
\hline 1 & $\begin{array}{l}\text { Negligible to slight damage in non-structural } \\
\text { elements and no damage in structural ele- } \\
\text { ments }\end{array}$ \\
\hline 2 & $\begin{array}{l}\text { Moderate damage in non-structural elements } \\
\text { and slight damage in structural elements }\end{array}$ \\
\hline 3 & $\begin{array}{l}\text { Heavy damage in non-structural elements } \\
\text { and moderate damage in structural elements }\end{array}$ \\
\hline 4 & $\begin{array}{l}\text { Very heavy damage in non-structural ele- } \\
\text { ments and heavy damage in structural ele- } \\
\text { ments }\end{array}$ \\
\hline 5 & $\begin{array}{l}\text { Very heavy damage in structural elements or } \\
\text { collapse of some parts or floors or total col- } \\
\text { lapse }\end{array}$ \\
\hline
\end{tabular}


were the nearest to the epicenter, where the number of damaged buildings in the sub-prefectures of Bordj Menail, Boumerdes and Boudouaou was very high compared to other neighboring areas in the prefecture (Fig. 11 and Fig. 12). The number of investigated apartment buildings was important compared to other type of facilities such as administrative, health and education facilities (Fig. 13). Actually, almost $45 \%$ of inventoried constructions in Boumerdes Prefecture were moderately to heavily damaged. More than $20 \%$ of apartment buildings, more than $20 \%$ of administrative buildings, more than $20 \%$ of educative facilities, more than $12 \%$ of health facilities, more than $27 \%$ of sport and cultural facilities, approximately $34 \%$ of commercial buildings and $30 \%$ of industrial buildings were heavily to very heavily damaged. Figure 14 illustrates the percentage distribution of damaged facilities in Boumerdes Prefecture.

\subsection{Distribution of damage in the prefecture of Algiers}

In Algiers Prefecture, the most affected areas were also the nearest to the epicenter (Fig. 15 and Fig. 16), and the number of damaged buildings in the sub-prefectures of Dar El-Beida and Rouiba was very high compared to other neighboring areas in the prefecture. A large num-

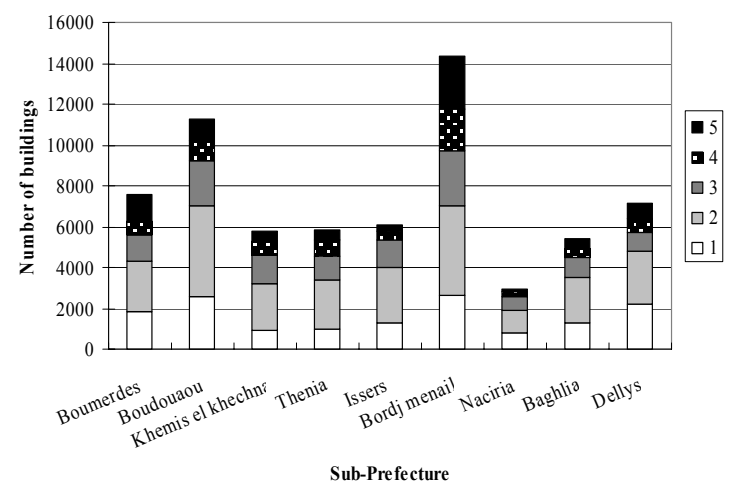

Fig. 11 Damage level distribution for inventoried buildings by sub-prefecture in Boumerdes Prefecture (DUC).

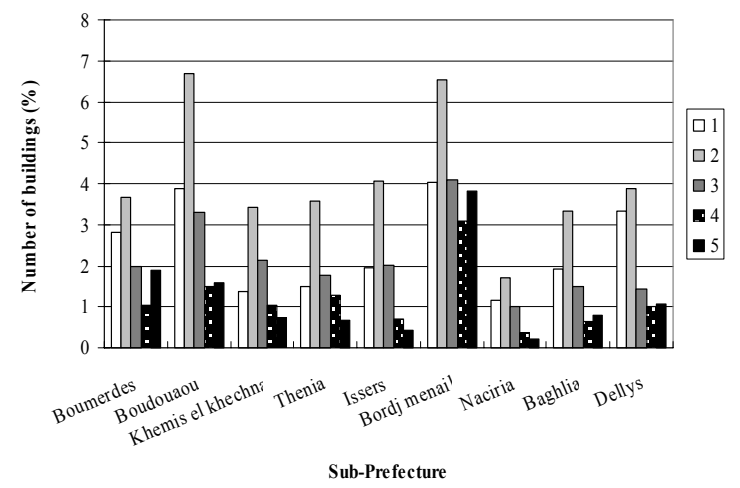

Fig. 12 Damage level distribution as percentage of total inventoried buildings in Boumerdes Prefecture (DUC). ber of buildings were investigated. As in Boumerdes Prefecture, the number of investigated apartment buildings was very high among the various types of facilities (Fig. 15 through Fig. 17). Actually, approximately 55\% of inventoried constructions in Algiers Prefecture were moderately to heavily damaged. Approximately $28 \%$ of apartment buildings, $12 \%$ of administrative buildings, more than $15 \%$ of education facilities, more than $10 \%$ of health facilities, more than $30 \%$ of sport and cultural facilities, approximately $12 \%$ of commercial buildings and more than $25 \%$ of industrial buildings were heavily to very heavily damaged. Figure 18 illustrates the percentage distribution of damaged facilities in Algiers Prefecture.

\subsection{Observed damages}

\subsubsection{Residential buildings}

Various deficiencies in construction or design induced various types of damages. The main causes of observed damages can be summarized as follows.

Cases of soft stories were nearly all observed in private reinforced concrete frame houses. The first story is always higher that the rest of the stories and is supported by slender columns without internal masonry infill walls (Fig. 19). Generally, the first story is used for commercial purposes.

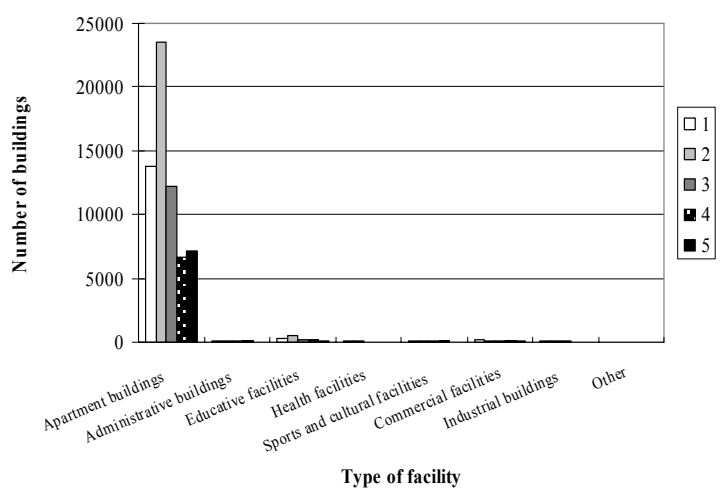

Fig. 13 Damage level distribution by type of facility in Boumerdes Prefecture (DUC).

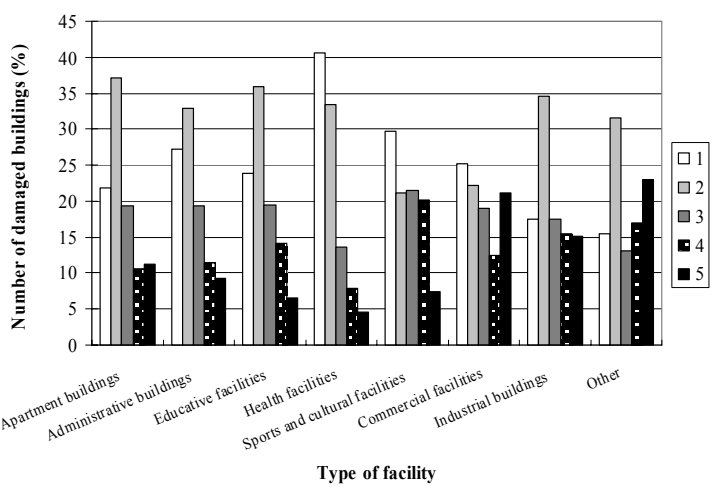

Fig. 14 Damage level distribution by category in Boumerdes Prefecture (DUC). 


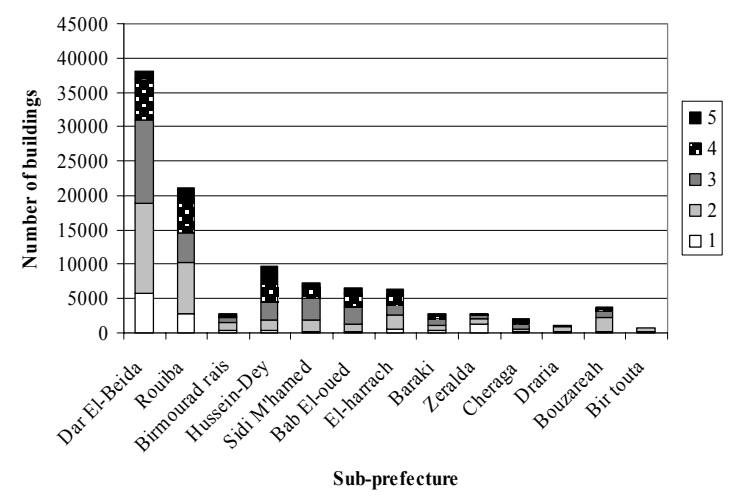

Fig. 15 Damage level distribution for inventoried buildings by sub-prefecture in Algiers Prefecture (DUC).

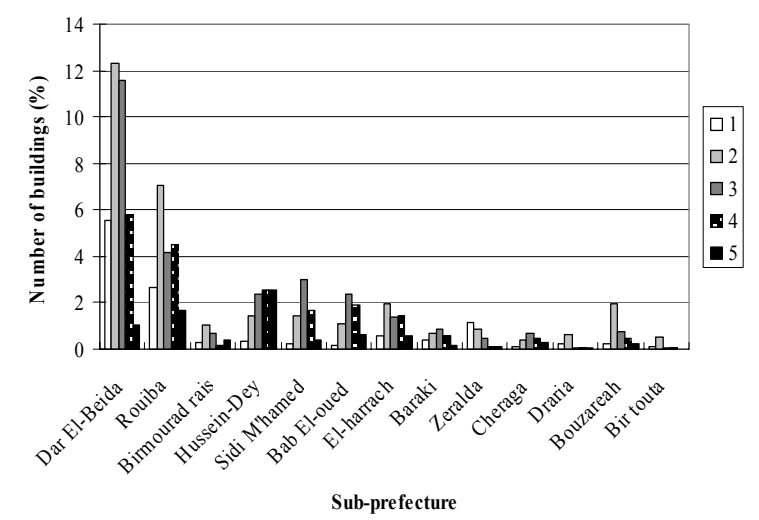

Fig. 16 Damage level distribution as percentage of total inventoried buildings in Algiers Prefecture (DUC).

The fundamental cause of the heavy damage is obviously an inadequately small design earthquake load and the insufficient lateral capacity of the buildings. The usual diameters used for the shear reinforcement are Ø6 or $\varnothing 8$ for individual buildings with maximum 4 stories. The shear reinforcements are either mild or deformed bars. Figure 20 shows damage suffered by first story squat columns near a staircase. Large spacing between ties was also one of the main causes of severe building damage. Large spacing was generally seen at the top of columns. In some cases, the untied region was approximately $40 \mathrm{~cm}$ (Fig. 21). Furthermore, the presence of very high first stories aggravated the damage. This fact explains why many structures had their first story totally damaged or even collapsed, while the upper stories suffered moderate to no damage.

Another cause is lack of shear reinforcement at beamcolumn joints. Even when the columns were well confined, buckling of longitudinal reinforcements took place in some places (Fig. 22). This was due to the absence of ties at beam-column joints. This failure mode was often seen in many of the damaged buildings.

Some of the observed damages in some buildings were not due to deficiencies in the buildings proper but were induced by the collapse of adjacent buildings, although the distance separating buildings was sometimes

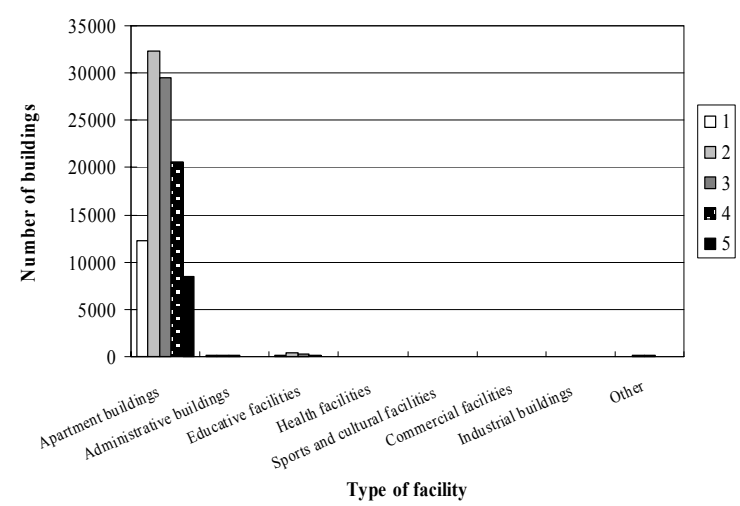

Fig. 17 Damage level distribution by type of facility in Algiers Prefecture (DUC).

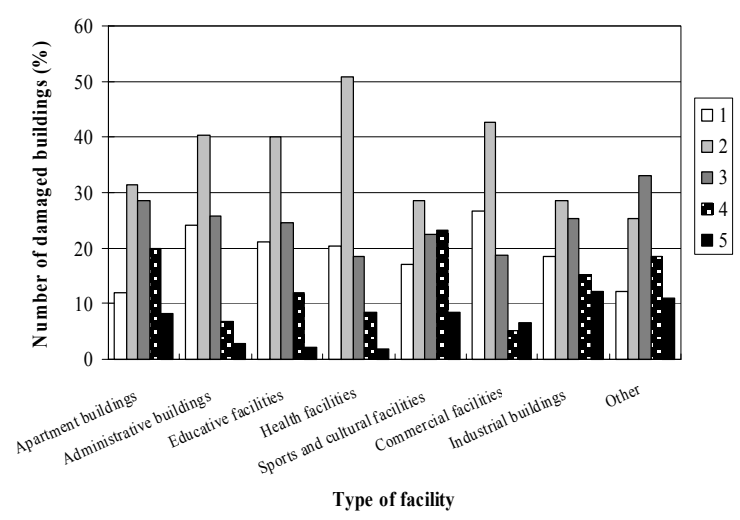

Fig. 18 Damage level distribution by category in Algiers Prefecture (DUC).

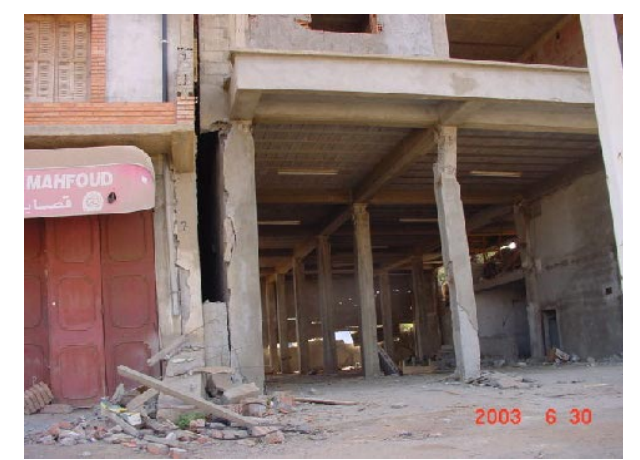

Fig. 19 Presence of soft story with slender columns at first story.

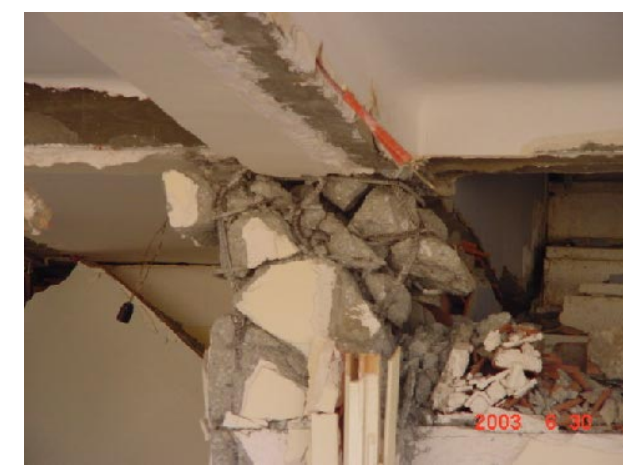

Fig. 20 Weak shear reinforcement along column height. 


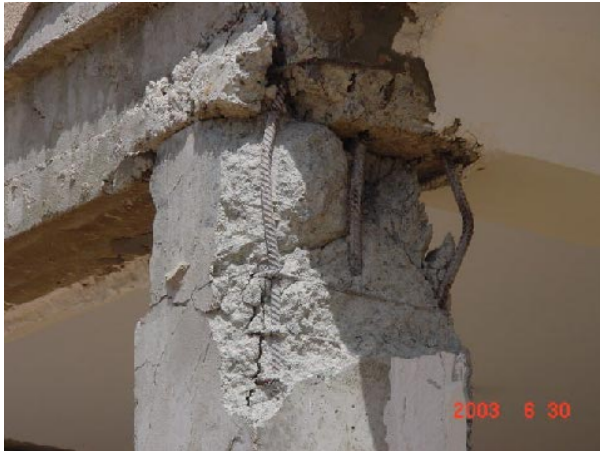

Fig. 21 Large spacing of stirrups at column top.

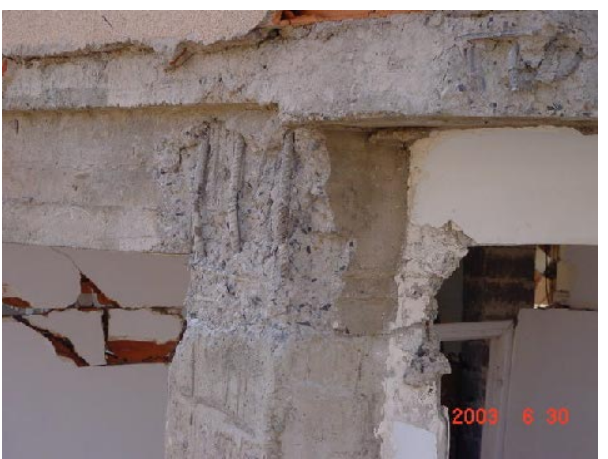

Fig. 22 Total lack of shear reinforcement at beamcolumn joint.

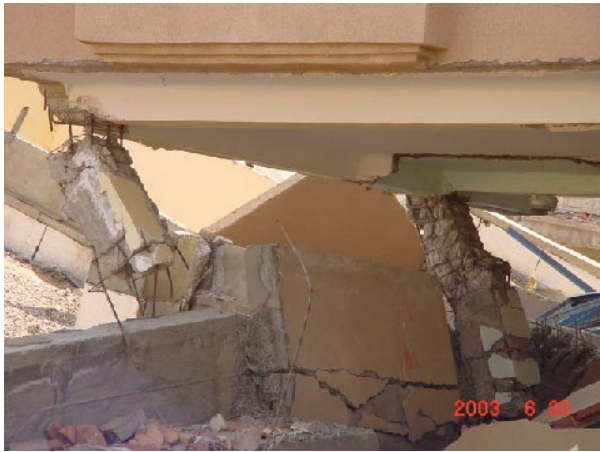

Fig. 23 Damage of first story due to total collapse of adjacent building.

more than seven meters. One such case is shown in Fig. 23.

Staircases, in general, are connected to the bearing systems, columns or walls, at mid height on each story.

Such construction process creates short columns that have a clear length less than half of the story height. This detail is often ignored while designing columns, resulting in a very different simulation behavior from the real one and as a consequence collapse may occur (Fig. 24).

Also, as mentioned previously regarding the construction procedures, hollow brick masonry walls are often used as nonstructural elements to separate different areas. In some cases, and especially for external infill walls, openings are created and the height of walls is not uniform over the entire story, creating short col-

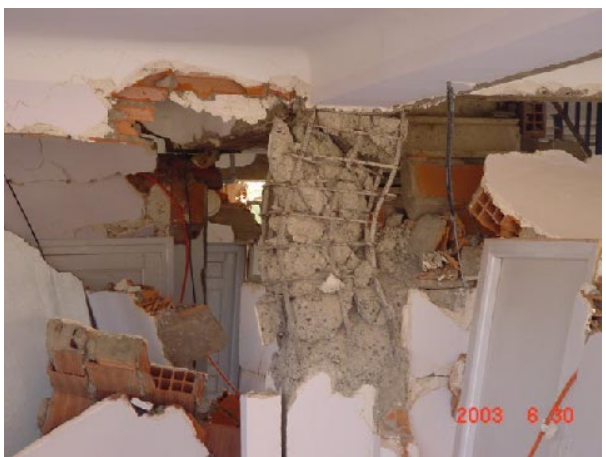

Fig. 24 Presence of short columns near staircase.

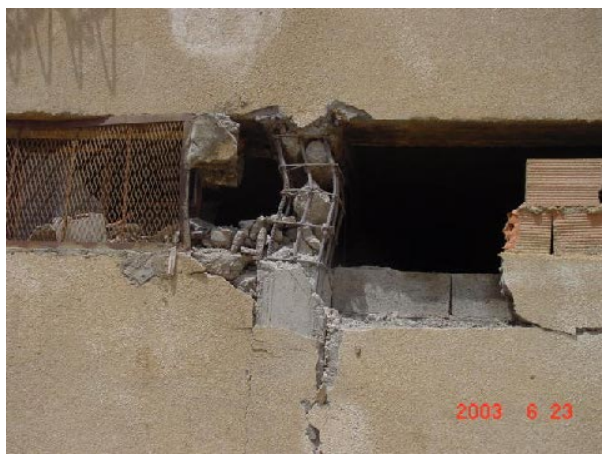

Fig. 25 Damage to external intermediate short column.

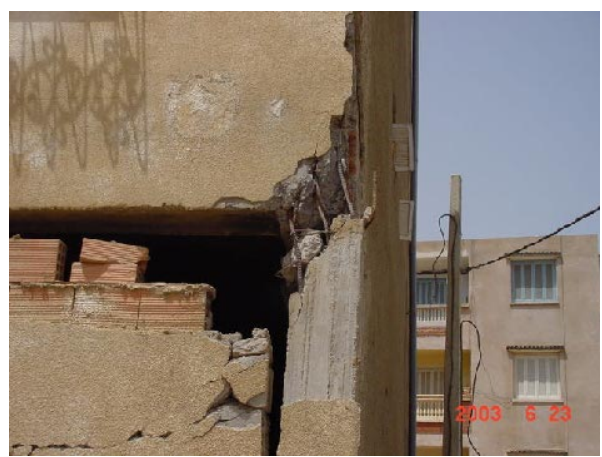

Fig. 26 Damage to corner short column.

umns with very little shear reinforcement. As a consequence, during an earthquake, such columns are severely damaged and this can sometimes lead to total collapse (Fig. 25 and Fig. 26).

In spite of the poor quality of concrete, good confinement saved, in some cases, buildings from collapse and allowed them to continue withstanding vertical loads. The first story columns of a 4-story building, for example, were severely damaged, yet the building continued withstanding vertical loads (Fig. 27).

Collapses of masonry infill walls were also observed due to excessive lateral drifts. Generally, internal and external masonry panels are constituted of hollow brick walls that are weakly connected to each other and not rigidly connected to frames at all, resulting in out-ofplane collapse (Fig. 28). In some old reinforced concrete buildings, the external wall of external panels is 


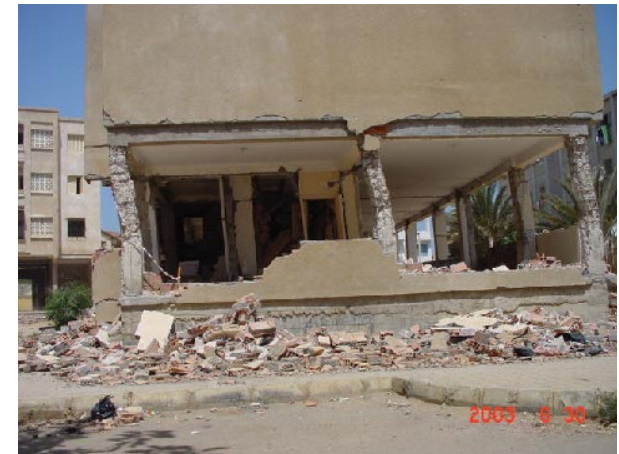

Fig. 27 Effect of confinement to withstanding vertical load.

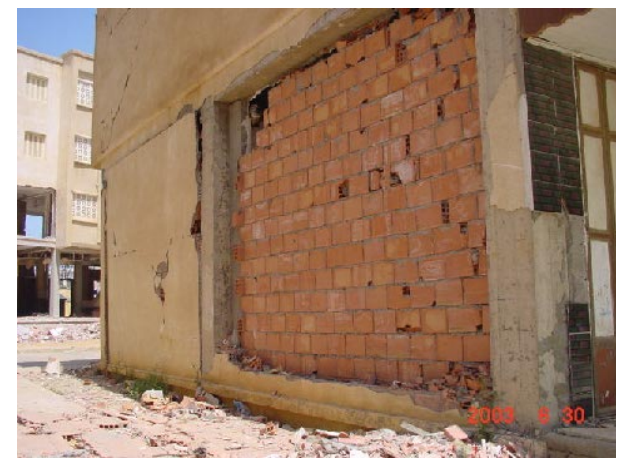

Fig. 28 Collapse of external infill walls of first story.

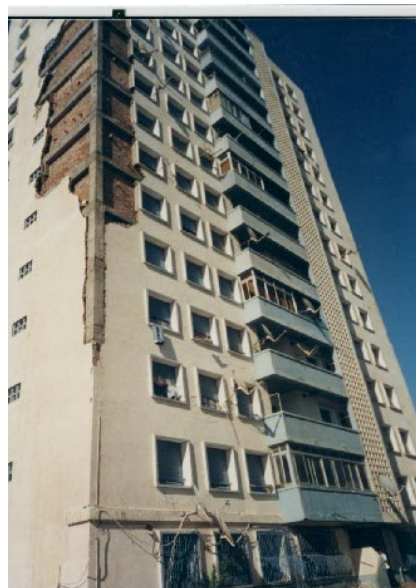

Fig. 29 Collapse of external infill walls of higher stories.

continuous from the first story to the last one without any ties, which make the building very vulnerable to horizontal shaking (Fig. 29).

In other cases yet, reinforced concrete prefabricated panels are used as external panels. These panels are connected to top and bottom floors by bolts and/or welding. The earthquake revealed the weaknesses in the connections of panels, which fell down from buildings (Fig. 30).

Insufficient joints between adjacent buildings caused moderate to severe damage to structures due to hammering phenomena (Fig. 31). Some blocks were completely destroyed, besides severe damages at the contact region.

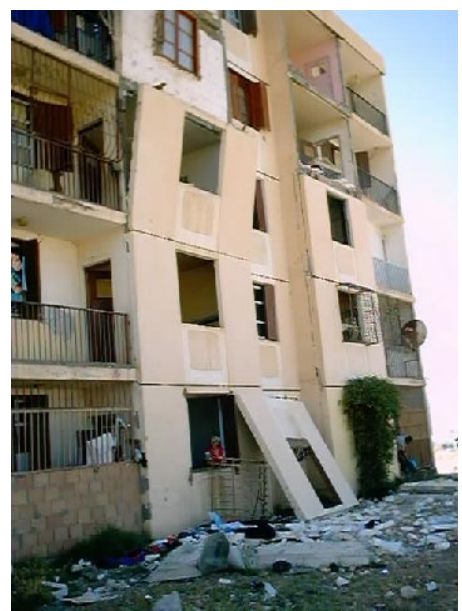

Fig. 30 Fall of prefabricated external panels from upper stories.

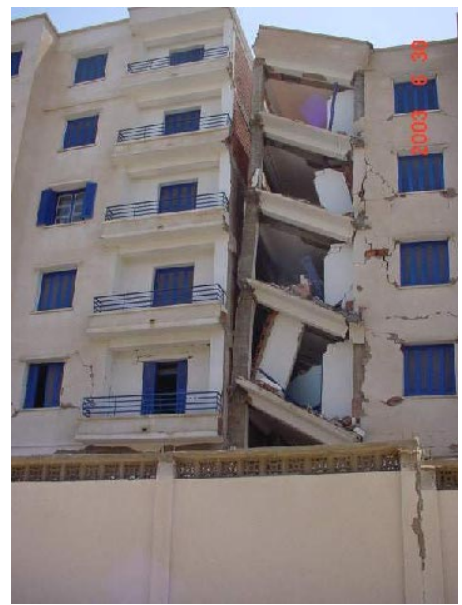

Fig. 31 General view of buildings damaged by hammering.

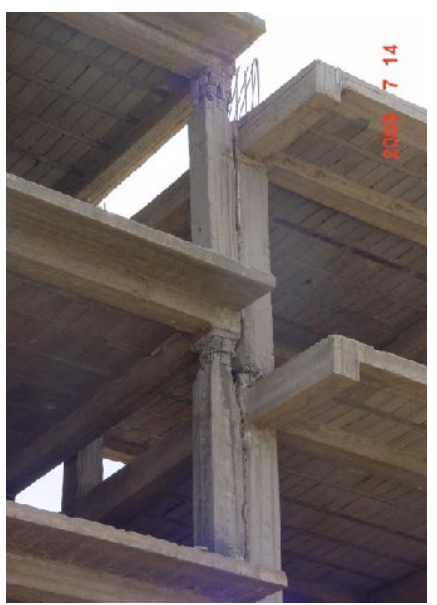

Fig. 32 Damage to columns due to pounding in frames without infill walls.

Hammering was found to be more dangerous when adjacent buildings had different story heights. During the earthquake, slabs hit the adjacent building's columns and caused important damage of the shear type. The 


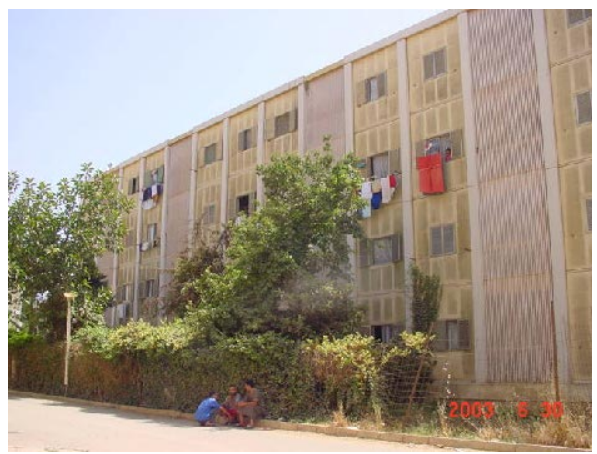

Fig. 33 Undamaged four-story steel structure.

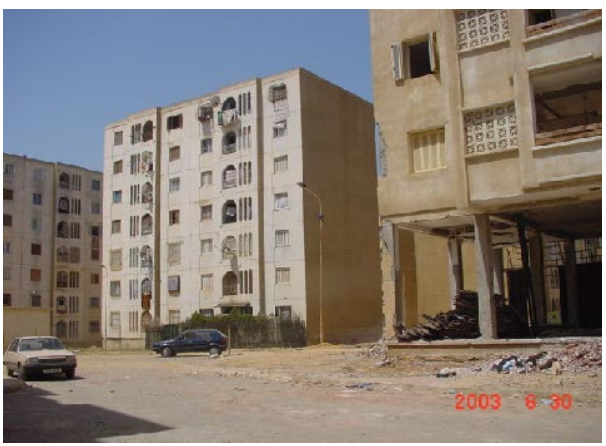

Fig. 34 Undamaged seven-story RC shear wall structure.

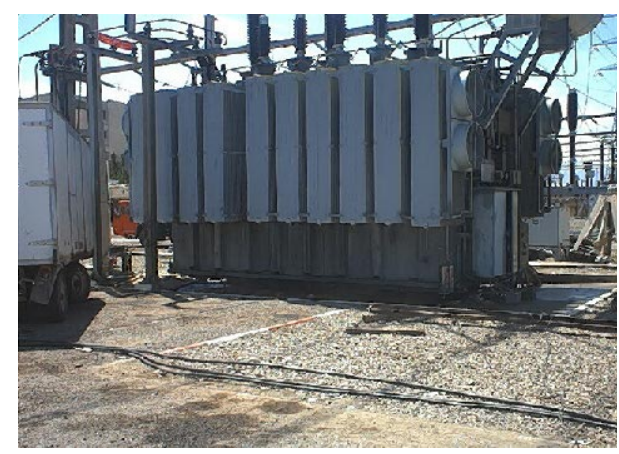

Fig. 35 General view of electricity transformer (CGS).

damage level was lesser for frame structures with infill walls than for structures under construction and without infill walls (Fig. 32). While reinforced concrete frame buildings were very damaged, steel structures (Fig. 33) as well as RC shear walls (Fig. 34) suffered slight to no damage. Slight buckling of simple bracings was the common damage for steel structures, while opening of prefabricated panel joints was often the observed damage on RC shear wall structures.

\subsubsection{Industrial buildings}

Generally, industrial facilities suffered less damage than residential ones. Industrial units and factories stopped their activities for two main reasons, lack of electric power and post-seismic investigations. Some large electricity-transformer plants also ceased operating due to the collapse of some generators (Fig. 35) or heavy damage of their bearing supports (Fig. 36), which made the

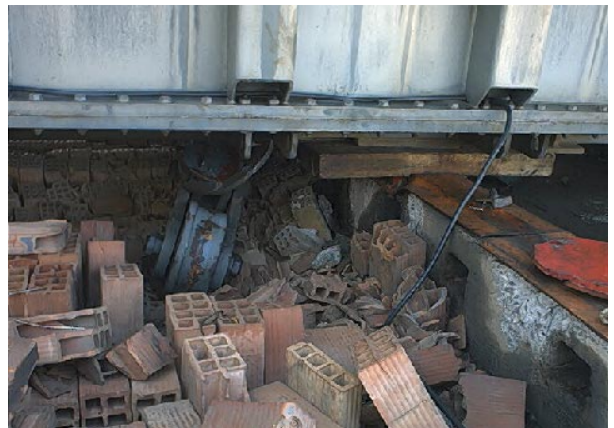

Fig. 36 Complete damage to bearing supports of electricity transformer (CGS).

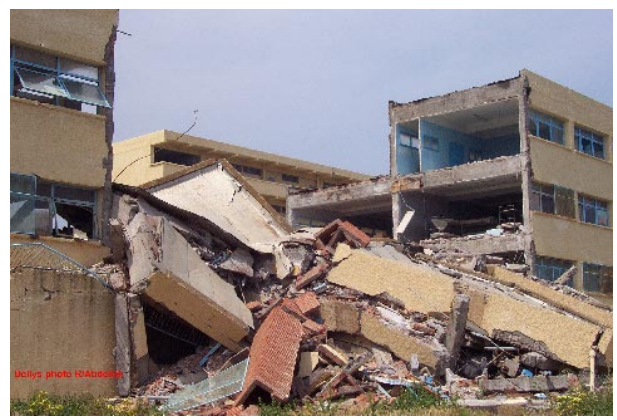

Fig. 37 Total collapse of block in junior high school (CGS).

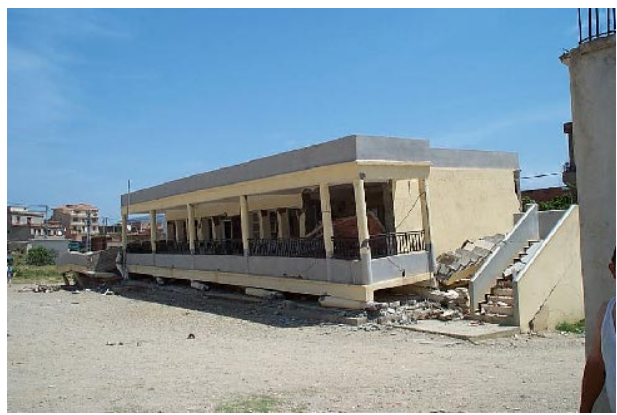

Fig. 38 Collapse of first story of elementary school (CGS).

generators unstable, particularly in Boumerdes Prefecture.

In the case of factories, damages were not of structural ones and no heavy damage or collapse was reported. The damage was mainly concentrated in equipment while building structures remained safe. For instance, some simply supported heavy appliances experienced significant slipping due to the large input acceleration. Moreover, some local pipes and bearing sup ports were damaged not because of strong shaking but due to the total absence of maintenance.

\subsubsection{School buildings}

During the earthquake, educational facilities were among the most damaged constructions after residential buildings. Classes and national exams were canceled in the affected prefectures, Algiers and Boumerdes. Some school buildings collapsed completely while others suf- 


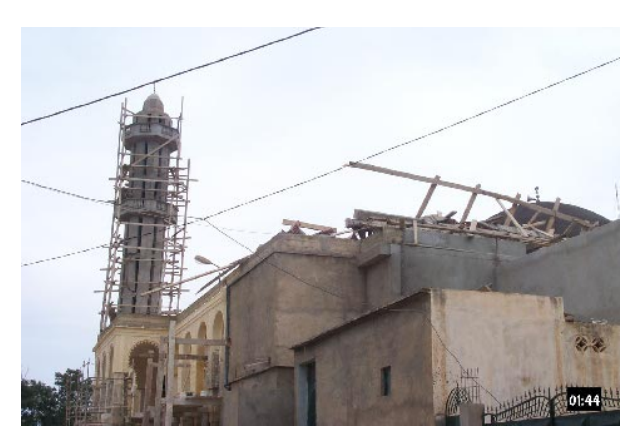

Fig. 39 Collapse of minaret under construction.

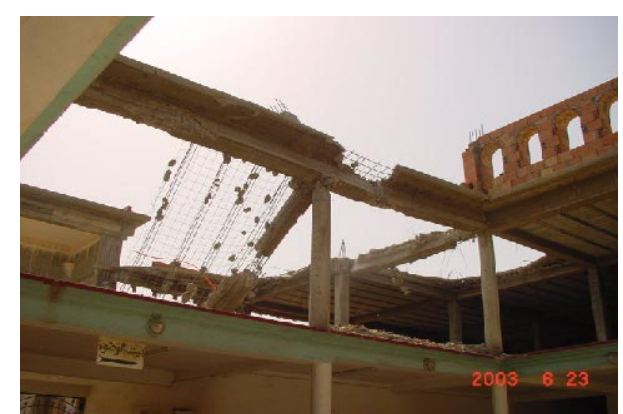

Fig. 40 Damaged mosque roof caused by collapse of minarets.

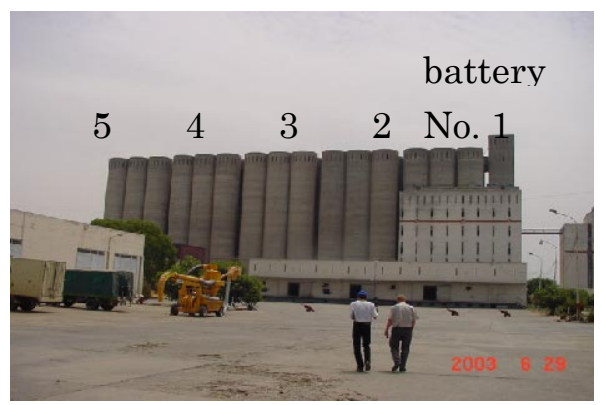

Fig. 41 General view of Corso-silos.

fered moderate to heavy damage. Fortunately the earthquake occurred in the evening when no classes were held. All the deficiencies that were noticed in residential buildings also applied to schools. However, school buildings were also characterized by a number of other typical aspects.

As a general observation, the presence of deep beams, which reduced the clear height of slender columns, were behind the total collapse of many blocks at some junior high schools (Fig. 37), resulting in rigid beam-soft column systems. This type of structure was very common during the seventies and the beginning of the eighties, when many similar schools were constructed in other prefectures.

Another typical damage at elementary schools with heavy floors and very slender columns is illustrated in Fig. 38. The first story totally collapsed while the second story suffered only slight damages.

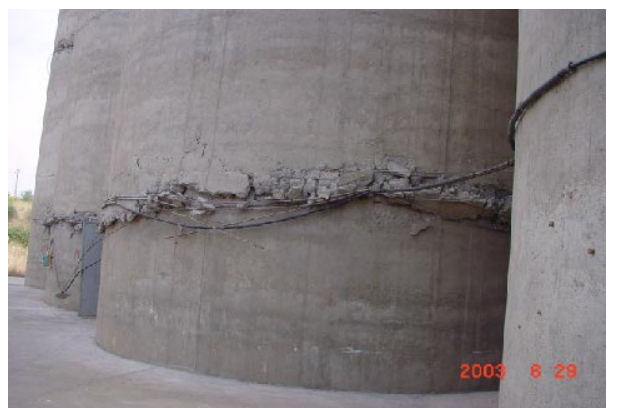

Fig. 42 Severe concrete crushing and buckling of longitudinal bars.

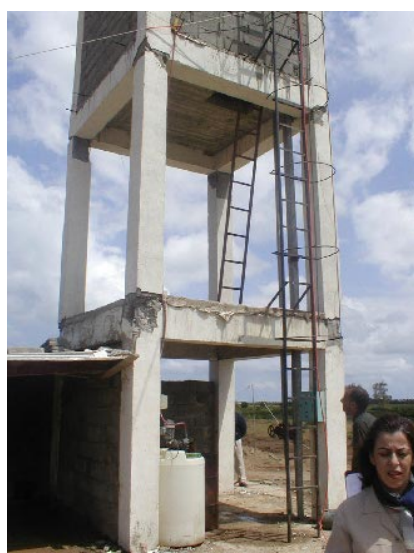

Fig. 43 Damage to old piloti water tower in Boumerdes (CGS).
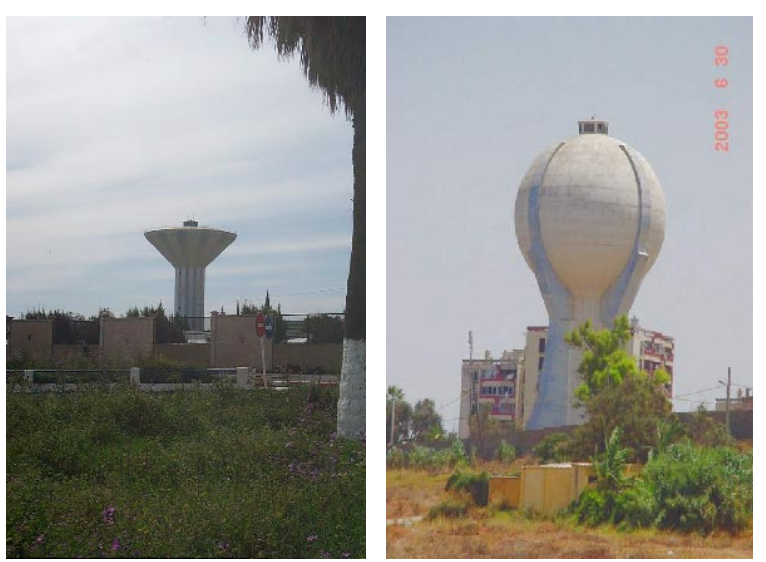

Fig. 44 Tall cone shape tower with moderate diameter at base and spherical shape tower with stiffeners.

Pure shear cracking of first story columns due to the presence of restraining elements and inducing short columns was observed in some schools. Also, the presence of wide side-balcony-corridors induced strong torsion forces during shaking that circular slender columns could not resist

\subsubsection{Mosques}

Many mosques were severely damaged during the earthquake. Almost all damaged mosques had been ex- 


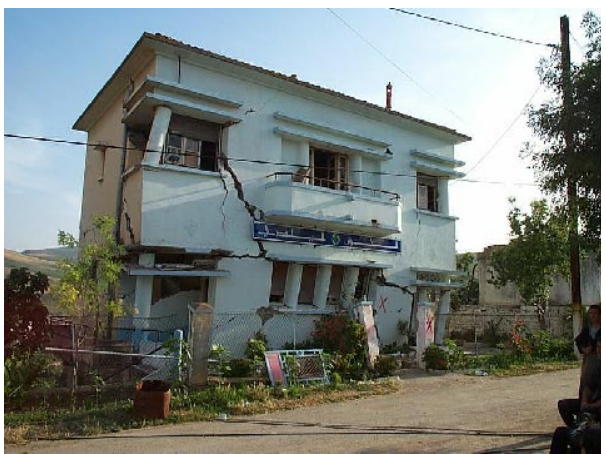

Fig. 45 Two-story damaged masonry building (CGS).

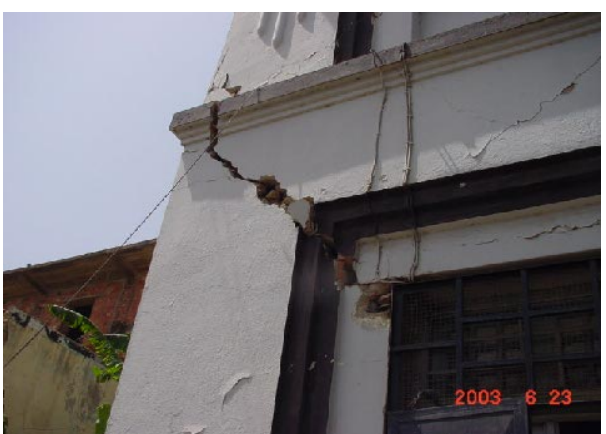

Fig. 46 Diagonal cracks and lack of ties at openings.

tended without any engineering work. Some extension work was being carried out when the earthquake occurred and could not sustain the tremors. Some minarets (towers) under construction completely collapsed (Fig. 39). When minarets fell down on the roof of the mosque they caused serious damage, especially on the slabs (Fig. 40). Damage due to hammering between extended part and the old structure of the mosque was also observed. This was mainly due to the fact that the new structure was built beside the old one without any separating joints. As a result, a lot of damage took place. Also, the pathological observations regarding residential buildings mentioned above also apply to mosques.

\subsubsection{Storage facilities}

The earthquake caused heavy damage to some storage equipment and facilities. Silos and some old and nonengineered water towers also fell victim to earthquake waves. The spectacular damage to the Corso-silos, which were constructed during the seventies near Boumerdes city, attracted many researchers and engineers (Fig. 41). Five batteries compose the complex, which is founded on piles that are $24 \mathrm{~m}$ in length. Each battery has 19 silos of different shapes: 9 cylindrical, 4 hexagonal and 6 rectangular silos. The silos are $66 \mathrm{~m}$ high and have a diameter of $8.5 \mathrm{~m}$. They were constructed using a climb-sliding form. The total storage capacity of the silos is 125,000 tons. Battery number five was the most damaged (Fig. 42). At the time of the earthquake, the battery was nearly full with grain, whereas other batteries were either approximately half

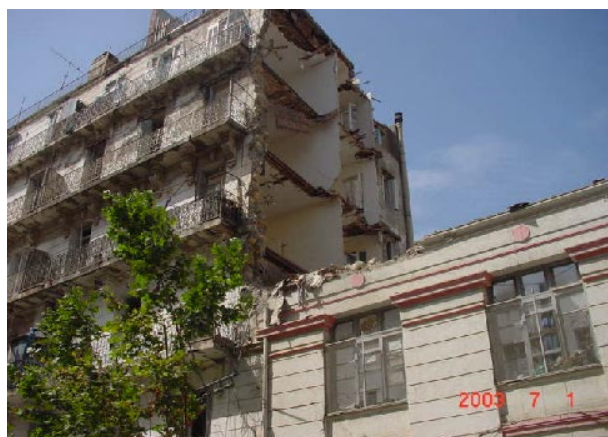

Fig. 47 Out-of-plane collapse of non-tied masonry facade.

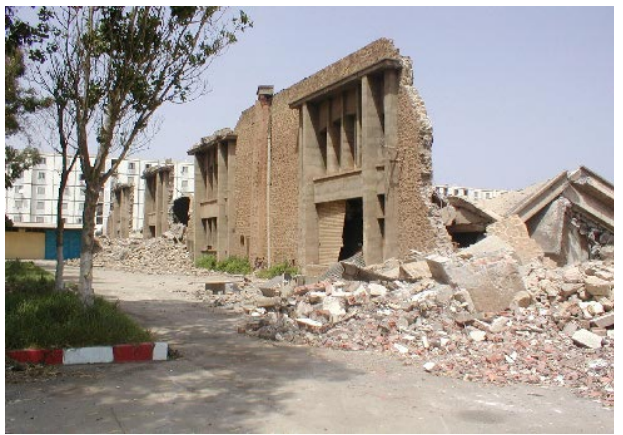

Fig. 48 Collapsed masonry sheds (CGS).

filled or almost empty. Severe concrete crushing, steelbar fractures and buckling, lack of reinforcements and partial sliding of the external concrete shell were observed. Moreover, the quality of the concrete and casting process seemed to have been inadequately mastered during construction.

As for water facilities, non-engineered and old water towers constructed on pilotis suffered moderate to heavy damage, especially at beam-column joints (Fig. 43).

Actually, the shapes, sizes and structural systems of water towers have changed considerably in the last twenty years. Towers consisting of reinforced concrete shells that span their entire height, with or without stiffeners, are the most commonly constructed in recent years. No serious damage was observed for such constructions in the affected area (Fig. 44).

\subsubsection{Stone masonry constructions}

In Algeria, such structures are at least 50 years old and were the most popular constructions before the introduction of reinforced concrete. The untied walls are usually, made with stones 40 to $60 \mathrm{~cm}$ thick. The floors are made of wood or brick arches supported by steel beams, filled with earth materials. Stone masonry buildings within $60 \mathrm{~km}$ of the epicenter suffered a lot from the earthquake. Typical damages, like diagonal shear of bearing walls, lack of ties near openings, weak connection between bearing walls and slabs, and out-of-plane failure of some walls were observed on almost all masonry constructions (Fig. 45 through Fig. 48). 


\section{Seismic hazard preparedness and disaster response}

Large cities and urbanized areas in Algeria contain large variety of not-well-maintained old constructions made of masonry stone walls with wooden floors, masonry stone walls with concrete floors, or reinforced concrete frames with brick infill walls, which are seismically very vulnerable and might induce huge losses if no reinforcing or reconstruction measures are taken soon. Also, although many new reinforced concrete buildings have been erected since the sixties, their seismic vulnerability is of concern due to the heightened risk level of the region, and the failure of many of these constructions to reach recent regulation levels and building requirements to ensure resistance to future earthquakes is a great matter of worry.

The Zemmouri earthquake has called to the reality of the Algerian patrimony and hazard preparedness, and is warning to society to proceed with serious changes in a timely manner before another major earthquake strikes. The earthquake caused heavy damages in two prefectures, Boumerdes and Algiers, affecting mainly apartment buildings, especially those constructed before the seventies and during the nineties. The demolition and clearing of collapsed constructions started early, while retrofitting and repair operations began two months after the earthquake. During this time, the rescue plan moved from the emergency to the temporary phase, while the government already voted for a special budget to reconstruct the affected prefectures and zones. Algeria also received help and loans from various countries and international financial organizations for reconstruction and the promotion of various social and economical sectors (Algériens du monde, 2003).

\subsection{Restoration phase}

In order to allow a rapid return to normal daily life after the earthquake, the government voted a special budget for emergency relief, repair and retrofitting of damaged constructions. The total amount of the budget was US\$1.85 billion (CG, 2003). To reach such goals in a very short time, many public and private design and construction companies were involved in the process, though without any call for tenders.

In the case of slightly damaged constructions, where only non-structural elements were affected, for instance hollow brick infill walls, the damaged elements are taken out and replaced with new ones.

In the case of moderate to severely damaged constructions, where non-structural and structural elements, beams, columns and shear walls were affected, damaged elements are repaired or replaced and in some cases, additional new structural elements, generally shear walls, are inserted into existing structures to upgrade them to sustain a higher risk.

\subsection{Administrative, technical and scientific is- sues}

As soon as the government received initial reports on losses and damage levels in the affected areas, prompt decisions were taken by the government as to the revision and effectiveness of the building permit system, contractors licensing, construction and material control procedures, and building regulations' applicability and conformity (CG, 2003). Judiciary procedures were also implemented after technical inventories were concluded. For instance, the Algerian administration stopped issuing building permits in almost all wards of Algiers and Boumerdes prefectures until debris was cleared. The introduction of a building insurance system for private constructions and updating of seismic zoning maps in some places were suggested for very near future revisions (CG, 2003; CGS, 2003). In order to take advantage of international experiences, such matters were discussed with all the foreign investigation teams and scientific or academic groups that visited Algeria after the earthquake.

\section{Lessons from the Zemmouri earthquake}

The 21 May 2003 Zemmouri earthquake exposed many problems and issues that must be objectively grasped. Many facts came to light, as follows.

1. Except for a few instances of liquefaction phenomena near rivers that affected some bridges and roads, few damages were linked to geotechnical problems.

2. The randomness of damage observed in various places, such as slopes, soft soil areas and seashore, led to the conclusion that damages resulted mainly from structural and quality deficiencies and was not due to topographical and geotechnical conditions.

3. Pounding problems, presence of soft stories, lack or absence of shear reinforcements in the columns, insufficient longitudinal steel bars, lack of shear reinforcement in beam-column joints, weak short columns, lack of confinement and weak concrete strength were the main causes of observed damages.

4. Collapse of external masonry infill walls and prefabricated RC panels, and collapse of constructions were another source of human injury and damage to cars and adjacent buildings.

5. Due to the absence of continuous and appropriate maintenance, earthquake shaking induced greater damage to old constructions. Also, due to the use of inferior quality materials and disregard of design requirements, newly constructed buildings suffered extensive damage.

6. Reinforced concrete frame constructions were the most damaged category. Steel frame structures and reinforced concrete shear walls suffered slight to no damage.

7. Apartment buildings and schools were the most damaged constructions compared to other infrastructure facilities. Private buildings and primary schools formed a considerable part of collapsed constructions.

8. With some exceptions, four to six story buildings 
were the most damaged construction category. However, tall buildings experienced slight or no damage.

9. Minarets, made of reinforced concrete, were the main parts in mosques that suffered heavy damage, if not total collapse.

10. Storage facilities, such as silos and old water towers on pilotis, suffered moderate to heavy damage. Water towers constructed of reinforced concrete shells were not damaged at all.

11. Stone masonry constructions suffered heavy damage, especially when untied and not well maintained.

12. Clearing of collapsed buildings started soon after any hope of finding people alive under collapsed constructions was lost. The repair phase started almost two months after the seismic event. Replacement of the damaged brick masonry walls, reparation of slightly damaged structural elements, and insertion of new reinforced concrete walls were the main tasks of the rehabilitation phase.

13. Many problems were faced in the process of gathering and analyzing various data. The failure to designate a specialized institution to lead the investigation process for buildings and facilities evaluation resulted in many inconvenient measures and unsuitable administrative, social and academic results.

14. Many inexperienced engineers and architects were called for the evaluation of different facilities as part of such investigations. The failure to continuously prepare and train teams to efficiently carry out postseismic investigation and evaluation activities resulted in very confusing reports and technical evaluations.

15. Changes and improvements made since El-Asnam earthquake (1980) in regulations and laws for the construction field have not lead to significant improvement in the quality of constructions, in terms of safety. This fact is not due to a lack of technical and scientific capabilities, but rather to widespread neglect and instability in the administration and construction communities.

16. Human loss was very high as a percentage of the total population in some small areas (ONS, 2003). Females, young adults and children were the most affected categories.

Although it is well known that the country has been facing and will face in the future many natural hazards and calamities, especially strong earthquakes, due principally to the seismotectonic setting of the Maghreb region, lack of awareness with regard to such events remains a major obstacle to ensuring the maintenance of normal social and economical activities in the face of such disasters. The 21 May 2003 Zemmouri earthquake has shown to Algerian authorities the lack of preparedness of various concerned parties for responding to such disasters. The enormous extent of human and economical losses caused by this recent earthquake highlight once again the necessity of major changes and heightened awareness toward such events.

While improving and changing regulations require some time as well as intellectual and practical efforts, these are not overly difficult tasks to achieve; however, raising people's consciousness toward such catastrophes and keeping them always aware of such events takes a lot of time and huge efforts from not only academics and engineers but also all other parties dealing with citizens in daily life.

Due to difficulties encountered when trying to obtain more detailed data about construction investigations, the authors made a field-scan of the entire affected areas and proceeded to perform detailed investigations of buildings in one region. Data analysis of the selected region, which was judged typical and acceptable enough for generalizing the conclusions to all the affected areas, revealed many important points. These findings are presented in a companion paper (Ousalem et al., 2005).

\section{Acknowledgements}

The authors gratefully acknowledge all the support provided by Professor Toshimi Kabeyasawa from the Earthquake Research Institute, The University of Tokyo, and Professor Fumio Watanabe from Kyoto University. Their laboratories' financial support made site visits and investigations possible. The assistance received from engineers and CGS's members in Algeria is also acknowledged.

\section{References}

Algériens du Monde (2003). "Quelques informations concernant le séisme [online]." France. Available from:

$<$ http://www.algeriensdumonde.org/info_seisme.htm $>$ [Accessed 10 July 2003].

Azurséisme (2003). "Séisme d'Algérie du mercredi 21 mai 2003 [online]." France. Available from: $<$ http://azurseisme.free.fr/seismeAlger.htm> [Accessed 23 July 2003].

Bossu, R., Godey, S. and Mazet-Roux, G. (2003). "EMSC actions concerning the BoumerdesZemmouri event." CSEM / EMSC Newsletter.

CG (2003). "Réunions, du 29 mai 2003, du 08 juillet 2003 et du 24 août 2003, du Conseil des Ministres entièrement consacré à la catastrophe nationale du 21 mai [online]." Algeria, Services du Chef du Gouvernement. Available from: $<$ http://www.cg.gov.dz/dossiers.htm $>$ [Accessed 02 September 2003].

CGS (1993). "Règles de Conception et de Calcul des Structures en Béton Armé, CBA 93." Document Technique réglementaire, National Center for Applied Research in Earthquake Engineering, Algerian Ministry of Housing.

CGS (1988). "Règles Parasismiques Algériennes, RPA 88." Document Technique réglementaire, National Center for Applied Research in Earthquake Engineering, Algerian Ministry of Housing.

CGS (1999). "Règles Parasismiques Algériennes, RPA 99." Document Technique réglementaire, National Center for Applied Research in Earthquake 
Engineering, Algerian Ministry of Housing.

CGS (2003). "Addenda 2003- Règles Parasismique Algériennes 1999." Document Technique réglementaire, National Center for Applied Research in Earthquake Engineering, Algerian Ministry of Housing.

CNGC (2003). "Séisme du 21 mai 2003 [online]." Algeria, Cellule Nationale de Gestion de la Crise. Available from: http://www.seismealgerie2003.dz/ [Accessed 15 July 2003].

CRAAG (2003). "Séisme du 21/05/2003 Région de Boumerdes [online]." Algeria, Centre de Recherche en Astronomie, Astrophysique et Géophysique. Available from: <http://www.craag.edu.dz/> [Accessed 13 July 2003].

DUC (2003). Directions de l'Urbanisme et de la Construction de la wilaya d'Alger et de la wilaya de Boumerdes

EQnet (2003). “Algiers, Algeria Earthquake, May 21, 2003 [online]." United States of America, EarthQuake Information Network. Available from: http://www.eqnet.org/FMPro/Web/archives/algiers.ht $\mathrm{m}$ [Accessed 15 July 2003].

ESC (1998). European Seismological Commision,
Subcommision on Earthquake Seismology, Working Group Macroseismic Scales, "European Macroseismic Scale, EMS-98." Cahiers du Centre Européen de géodynamique et de Séismologie, Volume 15, Grünthal, Luxembourg.

Laouami, N., Slimani, A., Nour, A. and Larbes, A. (2003). "Résultats préliminaires sur la caractérisation du séisme de Boumerdes du 21 mai 2003 (Choc principal)." Centre National de Recherche Appliquée en Génie Parasismique.

ONS (2003). "Population et démographie [online]." Algeria, Office National des Statistiques. Available from: <http://www.ons.dz/them_sta.htm $>$ [Accessed 15 July 2003].

Ousalem, H. and Bechtoula, H. (2003). "Report on the Damage Investigation and Post-Seismic Campaign of the 2003 Zemmouri Earthquake in Algeria." Earthquake Research Institute, The University of Tokyo, Ohbunsha Press.

Ousalem, H. and Bechtoula, H. (2005). "Inventory survey of the 2003 Zemmouri (Algeria) earthquake: Case study of Dergana city." Journal of Advanced Concrete Technology, Japan Concrete Institute, 3 (1), 175-183. 